\title{
Literacy Rates and its Impact on Birth Rates in Nadia District, West Bengal, India
}

Mahadeb Ghosh $^{+*}$ and Dr. Biswaranjan Mistri ${ }^{\top}$

\section{Abstract}

Equality in socio-economic component is essential for human development and social change. Educational inequality reduces economic growth and women's empowerment on the one hand and increases birth rate on the other. In population studies, it has been established that educational level is collinearly related with demographic behaviour. This study aims to investigate inequalities in literacy rates and its impact on birth rates in Nowpara-I Gram Panchayat (GP) located in the Krishnagar II C.D. Block, Nadia District of West Bengal using a household survey conducted in 356 households among women aged 49 and above in triangulation with secondary data. The aim of this study is to explore the causes of the spatial inequalities in education and its effect on spatial variations in birth rates. The key finding suggest that in Nowpara-I, negative relationships exist between female education and birth rate because education has a positive impact on empowerment, late marriage, use of contraceptives and family size.

Key words: Education, Inequalities, Female Education, Birth Rate, Household Survey, West Bengal, India

\footnotetext{
${ }^{\dagger}$ Assistant Teacher, Nakashipara High School, Nadia, Email: mahadebghosh2@gmail.com ${ }^{*}$ Corresponding Author

'Assistant Professor (Grade 2), Department of Geography, The University of Burdwan, Email: brmistri@gmail.com (C)2016 Ghosh and Mistri. This is an Open Access article distributed under the terms of the Creative Commons Attribution License (http://creativecommons.org/licenses/by/2.0), which permits unrestricted use, distribution, and reproduction in any medium, provided the original work is properly cited.
} 


\section{DOI: 10.20896/saci.v\%vi\%i.206}

\section{Introduction}

Equality in education is one of the key aims of Sustainable Development Goals 2030 but inequalities in education persist all over the place, albeit in varying degrees. The central aim of this research is to examine as to whether the female literacy rates bear an impact on the birth rates. Using a household survey in triangulation with secondary data, the research examines the inequalities in literacy rates and its impact on birth rates in Nowpara-I Gram Panchayat (GP) located in the Krishnagar II C.D. Block, Nadia District of West Bengal.

Inequality refers to those over which moral questions of right or wrong can arise such as differences among individuals in their wealth or educational qualifications (Johnston, 2000). It deals with the relative position of different individuals or households within a space implying that different individuals or households possess different amounts of same attribute or different attributes. Education is a social attribute, which differs from individual to individual within the household or among different households. It remains well documented that education is a moral right and very important component for human development and sustainable population growth. Fertility rate is another important component of population growth, and it is spatio-temporally varied due to different socioeconomic conditions. Higher education influences women's career aspirations, labour market involvement, familial roles and decisions regarding the number of birth (Rindfuss, Larry and St. John, 1980). Education affects both the level and timing of fertility. High level of fertility would nowhere persist for long in a society where mass education had been achieved (Caldwell, 1980). The difference in educational level has a strong effect on fertility. Indeed, education of the wife is a stronger determinant of fertility decisions than husbands' education (Breierova and Duflo, 2004). Women with low level of education reproduce at a higher rate when compared to women with higher educational level (Caldwell, 1980).
The disinheritance of women on the paternal property rights is a notable feature among Hindus, which is controlled mostly by customary practices. However, the Supreme Court has ruled that a Hindu woman or girl will have equal property right along with the male siblings on and from 9 September 2005. Women remain deprived of education in many societies in India is also a notable feature (Beteille, 1983). Negative relationships persisted between education and fertility, especially women's education and fertility rates because women's education has a positive impact on their autonomy, late marriage and use of contraceptives and reduced fertility (Mason, 1986; Singh, 1994). Female education and their participation in the labour force are important in reducing fertility rates and for the general improvement in social welfare in developing countries like India (Bongaarts, 1978 and Singh, 1994). Poor parents decide to have many children and invest little in education, thereby, increasing inequalities in education and fertility rate and lowering average literacy rates (Croix and Doepke, 2003). In case of rural India, poverty influences parental choice of how many children will go to school and up to what level (Ramachandran et al., 2003). Higher educated people, who spend a lot of time in looking for job to attain financial security and be socially established, get little time for reproduction. It consequently leads to the reduction in fertility rate among this section of people (Skirbekk, 2008).

In India, with the introduction of different policies such as The National Policy on Education (NPE), 1986, the literacy rates improved from $64.83 \%$ in 2001 to $74.04 \%$ in 2011. The 1986 NPE laid emphasis on the removal of disparities aimed at equalising educational opportunity, especially for Indian women, Scheduled Castes (SC) and Scheduled Tribes $(\mathrm{ST})^{1}$ communities. In order to overcome

\footnotetext{
${ }^{1}$ The Constitution of India recognises the SCs and STs as disadvantaged groups of people and belongs to the indigenous communities of the society (Bhattacharyya, 2009; 2013). According to the Census of India (2011), $16.6 \%$ and $8.6 \%$ are respectively SCs and STs of India.
} 
disparities and achieve social integration, NEP 1986 laid several clauses, some of which include on extension of scholarships, adult education, incentives for poor families to send their children to school regularly, etc. In addition, NPE1986 endorsed two approaches"child-centred approach" and "Operation Blackboard" to improve primary schools nationwide. The NPE 1986 was however modified in 1992, which stressed on the need for a radical reconstruction of the education system. The 1992 NPE gave much greater attention to science and technology, cultivation of moral values and a closer relation between education and the life of the people. Sarva Shiksha Abhiyan (SSA), launched in 2000-2001 was another attempt to provide opportunity for improving human capabilities amongst all children and thereby bridge social, regional and gender gaps with active participation of community in the management of schools (Government of India, 2000). Indeed, the central aim of SSA, as per the 86th Amendment to the Constitution of India, mandates universalisation of elementary education (aged 6-14) with in a stipulated time period. With the passing of the Right to Education Act on 1 April 2010 (Government of India, 2010), SSA has acquired the necessary legal force for its implementation. According to the Right to Education Act, "the state shall provide free and compulsory education to all children of the age of six to fourteen years in such a manner as the state may by law determine" (Anonymous, 2011). The Census data (2001 and 2011) unravels that with the improvement of literacy and health facilities, the birth rates as well as death rates have decreased (Census of India, 2001 and 2011). Negative relationship is found between literacy rates and birth rates and this relationship varies spatially in the country. The 2011 Census data unfolds that among the states, the average literacy rate of Kerala is highest 93.91\%; the state also enjoys highest female literacy rates, which stands at $91.98 \%$ indicating that not only the gender gap in literacy rate is the lowest (4.04\%) but also the birth rate is low, which stands at $14.8 \%$. The lowest literacy rate is found in the state of
Bihar (63.82\%), which is socio-economically a backward one (Human Development Report of India, 2010). Apparently, all the BIMARU (Bihar, Madhya Pradesh, Rajasthan and Uttar Pradesh) states are socio-economically poor with an average very low female literacy $(53.33 \%)$ and high birth rates (28.1\%). Among all the states of BIMARU, Rajasthan has a very low female literacy rate of $52.66 \%$ but a high birth rate of $26.7 \%$. Amongst the six union territories, Lakshadweep has the highest literacy rate of 92.28\% as per the 2011 Census data; seemingly, it has a low birth rate of $14.03 \%$. However, Dadra and Nagar Haveli have the lowest literacy rate among the union territories, which stands at $77.65 \%$; its birth rate is the highest, which is $26.6 \%$. The mean literacy rate of India has improved (8.49\%) from 2001 to 2011. The numbers of states having higher literacy rates than the national average have increased and standard deviations among the states have decreased. The consistency of equality in literacy rates has been developed from 2001 (15.26\%) to 2011 (10.41\%). Interstate inequality in birth rates still persists due to differential socio-economic development patterns in the country. In West Bengal, birth rate is (16.3) which are well below the national level (2011).

As argued by Karlekar, in 1983 in West Bengal, only forty graduates out of 1000 persons continued their higher education but inequality persisted among different castes and tribes. This increased to 72 graduates out of 1000 persons as per the Census of 2011. In rural areas however, gender inequality in education continues to persist and increases with the age of the children. School dropout is another major problem for girls for India as a whole, including West Bengal. Because of high dropouts, educational attainment of adults beyond primary school level is low (Choudhury and Sarkar, 2012). In the state, children are deprived of education because of inequality in their religion, caste and sex (Parul, 2014; Ali, 2014). Considering these backdrops, the research begins with an outlining of the objectives. This follows a brief description of the study area and the methodology deployed. 


\section{DOI: $10.20896 /$ saci.v\%vi\%i.206}

The final section discusses the findings from the research.

\section{Objectives}

Following are the main objectives of the research.

- To examine the spatio-temporal pattern of inequalities in education in the Nadia district.

- To analyse the reasons for inter-village disparities in education.

- To explore the impact of educational inequalities on birth rates.

\section{Study Area}

As stated above, the primary aim of this research is to examine the impact of inequalities in education on the birth rates in Nowpara-I GP of Krishnagar II C.D. block (Community Development Block) in Nadia District. It is almost universally established that there exists relationships between level of literacy and birth rates. Observations suggest that the birth rates are high in this area but there has been no previous systematic study on these issues. Geographically, the study area is located in between $23^{\circ} 28^{\prime} 15^{\prime \prime} \mathrm{N}$ to $23^{\circ} 32^{\prime} 30^{\prime \prime}$ $\mathrm{N}$ latitude and $88^{\circ} 26^{\prime} 15^{\prime \prime} \mathrm{E}$ to $88^{\circ} 30^{\prime} 15^{\prime \prime} \mathrm{E}$ longitude. The G.P. covers an area of 13.31 sq. $\mathrm{km}$. Total population of the area is 21417, consisting of seven revenue villages. Population density of the study area is 1609/sq. km.

\section{Database}

The study has been conducted based on primary data as well as secondary information. Primary data have been collected with the help of structured questionnaires from sevenrevenue village of Nowpara-I Gram Panchayat (G.P.). 356 households were surveyed taking women aged 49 and above as one of the criteria, that is, taking accounts of women who are heading towards their menopausal stage. Secondary information were collected from various sources, such as the District Census Handbook, Nadia (2011, Govt. of India), District Statistical Handbook, Nadia (2011, Govt. of West Bengal) and the office of $\mathrm{CMOH}$ Dy-II, Nadia, etc.

\section{Methodology}

Spatial pattern of educational inequalities and birth rates have been inferred from the analysis of the collected data through different statistical techniques. Standard Deviation and Coefficient of Variation have been calculated to find out temporal variation of consistency of literacy rates. Different levels of parents' education can cumulatively influence the birth rates. So, to compute the cumulative level of education of parents, Composite Index has been calculated. In addition, in order to measure the causal relationships between education and birth rates, correlation has been used and calculated using MS Excel 7. Computation of the intensity of the relationships between literacy rates and birth rates, regression analysis is being calculated using product-moment method. These computations are very useful in making prediction and assessing the relative influence of educational level on birth rates.

The coefficient of regression (t-test) helps to understand the significant level of existing influence of education. Analysis of variance is abbreviated as ANOVA. In this research, for significance test of independent factors, one way ANOVA has been computed. Through ANOVA technique, influences of independent variable on dependent variable have been investigated and calculated using data analysis tools of MS Excel 7. Gender Disparity Index (Kundu and Roy, 1983) has been calculated to probe the spatial as well as social inequalities in education, which in turn helps to explain the causality of birth rates. Gender Disparity Index is a composite measure, which reflects the differences between men and women. It is ranged from 0 (equal) to 1 (highly unequal). This index shows the disadvantage of women and loss in human development.

QGIS 2.8.1 has been used to represent thematic maps in addition to different cartograms, which are used for explanations of the relationships between inequalities in literacy rates and birth rates. 


\section{DOI: $10.20896 /$ saci.v\%vi\%i.206}

\section{Discussion and Findings}

West Bengal is an agro-based state where the birth rate has gradually decreased as witnessed in the last two decades. However, the birth rates were high until 1980 due to the demand of agricultural labours, underdeveloped health infrastructure and lack of family planning. The highest decadal decrease of birth rates are found in 1991 (27.2) to 2001 (20.7). According to the Census of India data (2011), the literacy rates of West Bengal were $77.08 \%$, which is above the national average of $74.04 \%$. The decadal rate of increase (with respect to 2001Census) was $8.44 \%$, when the national literacy rate was $68.64 \%$ (in 2001). The consistency of equality in literacy rates in the state have improved from $14.25 \%$ (2001) to $10.29 \%$ (2011). Due to varied socio-economic conditions and different infrastructural facilities across the state, the study found district-level inequalities in both literacy and birth rates. Among the 19 districts, literacy rates of nine districts are above state-average level. Purba Medinipur and Uttar Dinajpur bear respectively the highest (87.66\%) and the lowest (60.13\%) ranked districts in literacy rates. However, the lowest birth rate is found in the North 24 Parganas (3.71), while the highest is found in Murshidabad (27.75), which is one of the backward districts of West Bengal (Table 1). It is apparent from Table 1, that the districts whose literacy rates are generally higher have lower birth rates, albeit Kolkata is an exception. The high birth rates of Kolkata could attribute to migrated population and elites or middle class from the neighbouring states visiting Kolkata to deliver babies because of relatively better medical facilities.

\section{Table 1: Literacy Rate and Birth Rate in West Bengal, 2011}

\begin{tabular}{|c|c|c|c|c|c|c|c|c|c|}
\hline $\begin{array}{l}\text { Name of } \\
\text { District }\end{array}$ & $\begin{array}{l}\text { Purba } \\
\text { Medinipur }\end{array}$ & Kolkata & $\begin{array}{l}\text { North } 24 \\
\text { Parganas }\end{array}$ & Howrah & Hooghly & Darjeeling & $\begin{array}{l}\text { Paschim } \\
\text { Medinipur }\end{array}$ & $\begin{array}{l}\text { South } 24 \\
\text { Parganas }\end{array}$ & $\begin{array}{l}\text { Bardhama } \\
n\end{array}$ \\
\hline $\begin{array}{l}\text { Literacy } \\
\text { Rate (\%) }\end{array}$ & 87.66 & 87.14 & 84.95 & 83.85 & 82.55 & 79.92 & 79.04 & 78.57 & 77.15 \\
\hline $\begin{array}{l}\text { Birth } \\
\text { Rate }\end{array}$ & 17.26 & 22.12 & 3.71 & 10.02 & 13.91 & 23.91 & 18.90 & 7.48 & 6.73 \\
\hline
\end{tabular}

\begin{tabular}{|l|l|l|l|l|l|l|l|l|l|l|}
\hline $\begin{array}{l}\text { Name of } \\
\text { District }\end{array}$ & Nadia & $\begin{array}{l}\text { Cooch } \\
\text { Behar }\end{array}$ & $\begin{array}{l}\text { Dakshin } \\
\text { Dinajpur }\end{array}$ & $\begin{array}{l}\text { Jalpaigur } \\
\mathrm{i}\end{array}$ & Bankura & Birbhum & $\begin{array}{l}\text { Murshid } \\
\text { abad }\end{array}$ & Purulia & Maldah & $\begin{array}{l}\text { Uttar } \\
\text { Dinajpur }\end{array}$ \\
\hline $\begin{array}{l}\text { Literacy } \\
\text { Rate (\%) }\end{array}$ & 75.58 & 75.49 & 73.86 & 73.79 & 70.95 & 70.90 & 67.53 & 65.38 & 62.71 & 60.13 \\
\hline $\begin{array}{l}\text { Birth } \\
\text { Rate }\end{array}$ & 13.49 & 17.71 & 12.60 & 10.96 & 18.99 & 17.44 & 27.75 & 11.53 & 25.90 & 9.75 \\
\hline
\end{tabular}

Source: Calculation by Authors (based on the 2011 Census Data, Government of India)

\section{Inequalities in Literacy Rates in Nadia District}

The research demonstrates persistence of disparity in literacy rates between northern and southern parts of the Nadia district. Literacy rates in northern blocks are lower than that of the southern blocks. Haringhata registers the highest literacy rate of $82.15 \%$ while Karimpur has the lowest with $64.65 \%$ among all the blocks of the district (Table 2). Most important reasons of low literacy rates in Karimpur are low female literacy rate (62.85\%), low adult literacy rates $(34.65 \%)$ and lower academic grade index (13.90) in comparison to Haringhata $\quad(76.90 \%, 47 \%$ and 17.30 respectively). Academic Grade Index is a more powerful concept, which combines all the academic scales (Likert's five-point scale) except for illiteracy. Clearly, there are gender inequalities in literacy rates amongst the different blocks. Gender gap (GG) and gender inequality index (GII) are the lowest in Karimpur. In this block, both male (66.34\%) and female (62.85\%) literacy rates are lower than other blocks (Table 2, also Figures 1 and 2). In this district, blocks with high level of literacy rates (Hanskhali, Ranaghat and Haringhata) show medium gender inequalities in the same except for Chakdah (that shows high gender 
inequalities). Literacy rate (72.8\%) and gender inequalities in literacy rate $(0.089)$ is medium in Krishnaganj. In this block, the enrollment ratio, adult literacy rates and academic grade index are high. In Santipur and Ranaghat, the literacy rates are also high as $73.10 \%$ and $78.63 \%$ respectively (Table 2 ). Low literacy rate is also found in Krishnagar-II C.D. Block (68.52\%). In this block, $20 \%$ people have never gone to school and only $36 \%$ of the adults are literate (Human Development Report, Nadia, 2012). GG (12.54\%) and GII (0.122) in literacy rates are the highest in Nabadwip. Incidence of nonenrollment ratio is high (that is, $30 \%$ ) in this block.

\begin{tabular}{|c|c|c|c|c|c|c|}
\hline $\begin{array}{l}\text { Variables } \\
\text { and } \\
\text { Blocks }\end{array}$ & $\begin{array}{l}\text { Literacy } \\
\text { Rate } \\
\text { (Range) }\end{array}$ & Name of Blocks & $\begin{array}{l}\text { Gender } \\
\text { Disparity in } \\
\text { Education } \\
\text { (range) }\end{array}$ & Name of Blocks & $\begin{array}{l}\text { Birth } \\
\text { Rate } \\
\text { (Range) }\end{array}$ & Name of Blocks \\
\hline Low & $\begin{array}{l}64.60- \\
70.45\end{array}$ & $\begin{array}{l}\text { Karimpur, Tehatta, } \\
\text { Kaliganj, Nakashipara, } \\
\text { Chapra, Krishnagar II } \\
\text { and Nabadwip }\end{array}$ & $0.035-0.064$ & $\begin{array}{l}\text { Karimpur, Tehatta, } \\
\text { Kaliganj and Chapra }\end{array}$ & $\begin{array}{l}4.40- \\
8.82\end{array}$ & $\begin{array}{l}\text { Krishnaganj, } \\
\text { Hanskhali, Chakdah } \\
\text { and Haringhata }\end{array}$ \\
\hline Medium & $\begin{array}{l}70.45- \\
76.30\end{array}$ & $\begin{array}{l}\text { Krishnaganj, Krishnagar } \\
\text { I, and Santipur }\end{array}$ & $0.064-0.093$ & $\begin{array}{l}\text { Nakashipara, } \\
\text { Krishnaganj, Krishnagar } \\
\text { I and II, Hanskhali, } \\
\text { Ranaghat and } \\
\text { Haringhata }\end{array}$ & $\begin{array}{l}8.82- \\
13.23\end{array}$ & $\begin{array}{l}\text { Karimpur, Tehatta, } \\
\text { Kaliganj, } \\
\text { Nakashipara, Chapra } \\
\text { and Krishnagar II }\end{array}$ \\
\hline High & $\begin{array}{l}76.30- \\
82.15\end{array}$ & $\begin{array}{l}\text { Hanskhali, Ranaghat, } \\
\text { Chakdah and } \\
\text { Haringhata }\end{array}$ & $0.093-0.122$ & $\begin{array}{l}\text { Nabadwip, Santipur and } \\
\text { Chakdah }\end{array}$ & $\begin{array}{l}13.23- \\
17.64\end{array}$ & $\begin{array}{l}\text { Nabadwip, Santipur } \\
\text { and Ranaghat }\end{array}$ \\
\hline
\end{tabular}

\section{Source: Primary Census Abstract, Nadia District, Govt. of India, 2011 (calculated by authors).}

\section{Inequalities in Literacy Rates in Nowpara-I G.P.}

In Nowpara-I G.P., literacy rate is $70.14 \%$, which is lower than the national, state and district level but more than the block level (Krishnagar II C.D. block, 68.52\%). Male and female literacy rates are $70.75 \%$ and $69.54 \%$ respectively. Inter village inequalities in literacy rates are found in the study area due to inequalities in sociocultural and economic variables. Among the General Castes $^{2}$, the literacy rate is $77.33 \%$, which is more than other castes and classes (Table 3). Moreover, the literacy rates among the Hindus stand at $74.62 \%$, which is more than the Muslims are (67.72\%). In Natun Nowpara, which a revenue village, the literacy rate is highest $(85.45 \%)$ here but the lowest in Jotinagar $(51.14 \%)$, which is another revenue village. However, observations show that Natun Nowpara is more developed when compared to Jotinagar. This is because villagers of Natun Nowpara not only own agricultural lands but

\footnotetext{
${ }^{2}$ The groups people, who do not qualify for any of the positive discrimination schemes operated by the Government of India, are known as general castes and they are considered socially, educationally and economically advanced (Bhattacharyya, 2009; 2013).
}

majority of the parents are willing to send their children to school but in Jotinagar, not only female and adult literacy rates are low but villagers are mostly agricultural labourers and socio-economically backward. Literacy rates in other revenue villages Singhati, Nowpara Coloni, Jhitkepota and Harindanga, Armia is respectively $76.78 \%, 76.77 \%, 74.55 \%, 72.82 \%$ and $65.92 \%$.

There are gender differences notwithstanding in literacy rates. In this G.P., the gender gap $(1.21 \%)$ in literacy rate is lower than the district level (7.77\%) and the block level (10.42\%). The GII is 0.012 because of low literacy among the males and females as well as low average literacy rate. The GG in literacy rate is lowest in Singhati (2.95\%) and highest in Jotinagar (18.15 $\%)$. GII is highest in Jhitkepota (0.100) and lowest in Harindanga (0.002) (Figure 3). In Harindanga, however, the female literacy rate $(72.5 \%)$ is more than male literacy rate $(71.82$ $\%)$. In Jhitkepota, GG (10.76 \%) and GDI (0.100) are more than the district and block levels. It is to be noted that $48.94 \%$ households live in below poverty line and among the mothers, only $38.89 \%$ are literate at primary $(11.11 \%)$, 
upper primary (11.11\%), secondary (5.56\%) and higher secondary level (11.11\%).
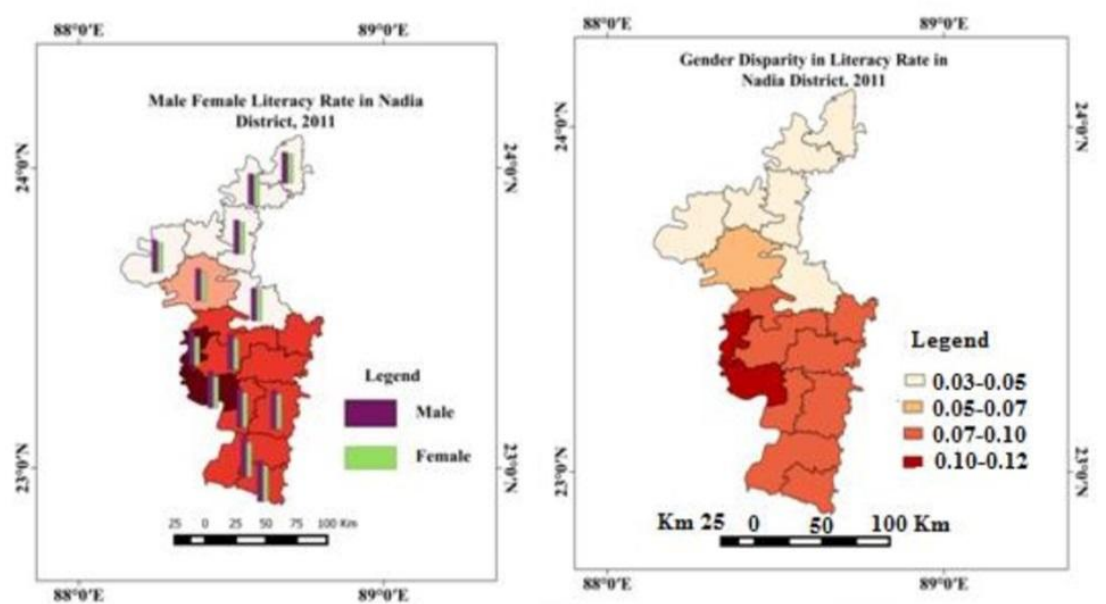

Fig.1 Gender Gap and Gender Disparity in Literacy Rate in Nadia, 2011

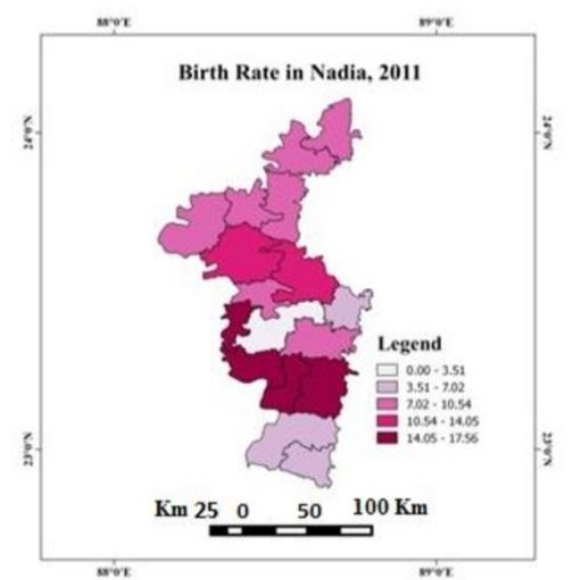

Fig. 2. Inequality in Birth Rate in Nadia,2011 

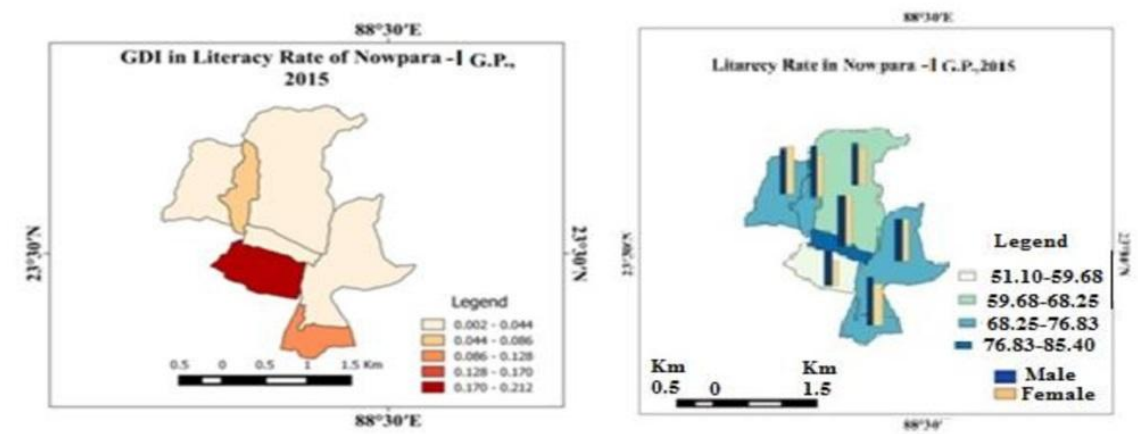

Fig. 3. Gender Gap and Gender Disparity in Literacy Rate in Nowpara-I G.P, 2015

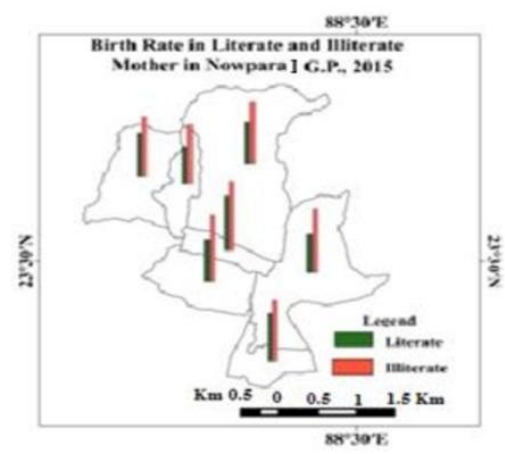

Fig. 4. Birth Rate According to Literacy

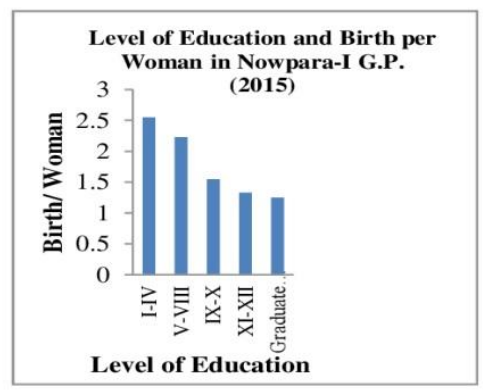

Fig. 5. Birth Rate in different Mothers

\section{Table 3: Literacy Rate among Different Caste, Class and Religion in Nowpara-I G.P, 2015}

\begin{tabular}{|c|c|c|c|c|c|c|c|c|c|c|}
\hline $\begin{array}{l}\text { Caste } \\
\text { and } \\
\text { Religion }\end{array}$ & \multicolumn{2}{|c|}{ General } & \multicolumn{2}{|c|}{ SC } & \multicolumn{2}{|c|}{$\mathrm{OBC}$} & \multicolumn{2}{|c|}{ Hindu } & \multicolumn{2}{|c|}{ Muslim } \\
\hline $\begin{array}{l}\text { Literacy } \\
\text { (\%) }\end{array}$ & \multicolumn{2}{|c|}{77.33} & \multicolumn{2}{|c|}{71.82} & \multicolumn{2}{|c|}{76.85} & \multicolumn{2}{|c|}{74.62} & \multicolumn{2}{|c|}{67.72} \\
\hline Gender & Male & Female & Male & Female & Male & Female & Male & Female & Male & Female \\
\hline Literacy & 81.10 & 73.33 & 71.88 & 71.77 & 77.06 & 76.60 & 75.93 & 73.29 & 69.55 & 65.94 \\
\hline
\end{tabular}

(\%)

\section{Source: Primary Survey, 2015}


Inequalities in Level of Education in Nowpara-I G.P

Level of education is a robust indicator of social development but it varies in different sociocultural and economic conditions. In the study area, $84.07 \%$ of literate females fall in the category of class I to class $X$ and the remaining $15.93 \%$ are pursuing education in between class XI-XII to post-graduate (Table 4). Females are able to achieve primary, upper primary and secondary level of education like their male counterparts but with the increasing level of education, the percentage of female students decrease. Boys are more likely to get more opportunity than the girls to pursue further education-that is, higher secondary, undergraduate or postgraduate level of education. This is primarily due to scarcity of higher educational institutions in the local areas, distance of the institution from home, problems in communication using public transport, etc. At upper-primary level, the percentage of students (36.41\%) is more than other levels of education (Table 4), and it is alike for boys (33.95\%) and girls (38.96\%). With the implementation of Right to Education Act, students up to class VIII are now entitled to book grants, uniform grants and different types of scholarships from the Government of West Bengal and Government of India. Despite the implementation of the Right to Education, gender inequalities continue in the level of education all over the state similar to the rest of the country; perhaps a rough ride ahead before gender equalities in education could be fully accomplished all over India. This research has found some interesting facts in this G.P., the percentage of female students are higher than the percentage of male students in upper primary (38.96\% and $33.95 \%$ respectively) and secondary $(21.69 \%$ and $20.11 \%$ respectively) levels of education. In Armia, Singhati, Jotinagar and Jhitkepota, the percentage of females at the primary level are higher but in Natun Nowpara, Armia, and Nowpara Coloni, the percentage females are higher at secondary level. This is because, these areas are mired in extreme forms of poverty, where the teenaged boys are compelled to earn money to manage the economic burdens of the families; therefore, most boys give up their studies but the girls of these areas continue their education. At higher-secondary levels in Singhati, Harindanga and Natun Nowpara, enrolment rate of the females is $12.64 \%, 9.28 \%$ and $7.55 \%$ respectively, which is higher than the enrolment rate of the males $(8.86 \%, 9.18 \%$ and $4.88 \%$ respectively). However, in the case of undergraduate and postgraduate courses, the percentage of females is lower than that of the males. Evidence suggests that in this G.P., $56.43 \%$ girls were married off before they had attained the legal age of 18 years and had to give up their education. Moreover, there is no college in this block-two colleges are located respectively at distances of $15 \mathrm{kms}$ (at Krishnagar) and approximately $20 \mathrm{kms}$ (at Bethuadahari).

\section{Table 4: Inequality in Level of Education in Nowpara-I G.P. (2015)}

\begin{tabular}{lcccccccc}
$\begin{array}{l}\text { Level } \\
\text { Literacy }\end{array}$ & $\begin{array}{l}\text { Nowpara-I } \\
\text { G.P. }\end{array}$ & Harindanga & Singhati & $\begin{array}{l}\text { Natun } \\
\text { Nowpara }\end{array}$ & Armia & Jotinagar & $\begin{array}{c}\text { Jhitkepota } \\
\text { Nowpara } \\
\text { Coloni }\end{array}$ \\
\hline I-IV & 25.97 & 16.27 & 25.69 & 23.40 & 28.57 & 31.11 & 30.47 & 30.92 \\
\hline V-VIII & 36.41 & 37.95 & 35.91 & 41.49 & 34.69 & 42.22 & 43.75 & 34.20 \\
\hline IX-X & 20.88 & 26.51 & 16.70 & 21.28 & 22.45 & 20.00 & 15.63 & 23.68 \\
\hline XI-XII & 8.84 & 10.84 & 9.23 & 6.38 & 7.48 & 6.67 & 8.59 & 11.18 \\
\hline $\begin{array}{l}\text { Above } \\
\text { Graduate }\end{array}$ & 7.90 & 8.43 & 12.47 & 7.45 & 6.81 & 00 & 1.56 & 5.92 \\
\hline $\begin{array}{l}\text { Total } \\
\text { Thoturce }\end{array}$ & 100 & 100 & 100 & 100 & 100 & 100 & 100 & 100
\end{tabular}

Source: Primary Survey, 2015 


\section{DOI: 10.20896/saci.v\%vi\%i.206}

\section{Inequalities in Birth Rates in Nadia}

Nadia lies in the middle among the districts of West Bengal with respect to birth rates and ranks 9th among the 19 districts. Indeed, there are inter block inequalities in birth rates and ranges from 4.34 in Haringhata to 17.56 in Nabadwip. Low birth rate is also found in Krishnaganj, Hanskhali and Chakdah (Table 1). In these blocks, the literacy rates ranges from medium (Krishnaganj) to high (Hanskhali and Chakdah) and socio-economic conditions are relatively better. The birth rate is medium (8.82-13.23) in Karimpur, Tehatta, Kaliganj, Nakashipara and Chapra. High birth rates (13.23-17.64) are found in Nabadwip, Ranaghat and Santipur (Figure 2). In these blocks, urban settlements have developed and block hospital has been established. Due to these facilities, Nabadwip, Ranaghat and Santipur have shown highest birth rates. First principal component of birth rate is male literacy for Karimpur, Kaliganj, Chapra and Santipur, and female literacy for Chakdah and Hanskhali. Krishnagar-I C.D. block have shown to have the highest birth rate (67.59) because this is a town in the district. Besides, medical facilities are better than the other blocks. So, this block has been excluded from the study. In Krishnagar II C.D. block, literacy rate $(68.52 \%)$ is low and birth rate is medium.

\section{Inequalities in Birth Rates in Nowpara-I G.P.}

It remains well documented that education is an important component to control birth rate and consequently population growth rate. Among the literate mothers, birth rate is $\mathbf{2 . 3 5}$ per woman and it is higher among the illiterate mothers, which is 3.19 per woman (Figure 7). Literate women spend time for education and marry late. Educated women remain more informed about family planning, use of contraceptive tools and are more empowered to take decisions about family and the number of births. Increasing level of education increases the age of marriage and reduces reproductive time span of life. In the study area, birth rate is higher (2.55/ woman) among women with primary level of education and lower with increasing level of education of women (upper primary 2.23, secondary 1.55, higher secondary 1.33, graduate and post graduate 1.25 per woman respectively). Among the different religions, the number of birth per woman is lowest among the Hindus (2.31) and highest among the Muslims (3.19). At secondary, higher secondary, graduate and postgraduate levels of education, the percentage of Hindus are higher than the percentage of Muslims in the study region. With respect to General Castes, among the Hindus, the birth rate per woman is lower to the corresponding level of education (I-IV 2.25, V-VIII 2.06, IX-X 1.60, XI-XII 1.25 and Under and post graduate level 1.00 per woman) than other castes and classes (Figure 5). In this G.P., the number of births are lower among the General Castes (2.14) followed by SC (2.45) and Other Backward Communities (OBC) (2.35) (Figure 6). Among the illiterate mothers, the birth rates are higher in every village when compared to the literate mothers (Figure 4). In Nowpara Colony, the birth rate among illiterate mothers (3.00/woman) is lower than the illiterate mothers of other villages. Among illiterate mothers, in Jotinagar, Harindanga, Armia, Jhitkepota and Singhati, birth rates per woman are 3.41, 3.25, 3.22, 3.11 and 3.09, respectively. In Nowpara Colony, a village health centre is located and the mothers have access to medicines and contraceptives. In this village, the illiterate mothers became aware about family size from the neighbouring literate mothers and Accredited Social Health Activist (ASHA). The birth rate, which is 3.50 /woman, is highest among the villages found in Natun Nowpara. Muslim population solely inhabits this village, where only $7.55 \%$ of literate females have passed secondary level of education. In Singhati, Harindanga and Natun Nowpara, the birth rates are 1.56, 1.75 and 2.00 per woman respectively among the mothers with secondary level of education. The birth rates are low in every village amongst mothers with graduate and postgraduate levels of education (Harindanga 1.33, Singhati 1.20, Armia 1.00 and Natun Nowpara 1.00 per woman). 
Inter-village inequalities in birth rates are also found due to different socio-economic conditions in this GP. In Nowpara Colony, the birth rates among literate mothers are lower (1.88/woman) than other villages. Our computation unfolds that the level of mothers' education have controlled the birth rates ( $r=-$ 0.51 ) and it is significant at $2 \%$ level for 2 degree of freedom (f.d.). The level of mothers' and fathers' education cumulatively controls the birth at $1 \%$ level of significance for 2 degree level of freedom. Natun Nowpara has shown the highest birth rate among literate mothers (2.8/ woman). In this village, it is only the level of mothers' education which significantly ( $5 \%$ level) controlled the birth rates but the level of parents' education was not found to be significant in controlling birth rates. In Jotinagar, neither the level of mothers' education nor level of fathers' education controlled the birth rates but the level of income with the level of education did control the birth rates at $1 \%$ level of significance for 2 degree of freedom. Harindanga is at the second lowest position according to the number of birth per woman. In this place, mothers' and fathers' educational level controls the birth rates and it is significant at $1 \%$ level. Jhitkepota shows the same scenario. In Armia, mothers' educational level controls the birth rates and remains significant at $1 \%$ level. For Singhati, it is significant at $5 \%$ level.

In sum, Mothers' education, parents' education and income level are significant influencing factors of birth rates ( $F$ value is more than critical $F$ value) and standard error of residuals ranges from 1.27 to 1.41 .
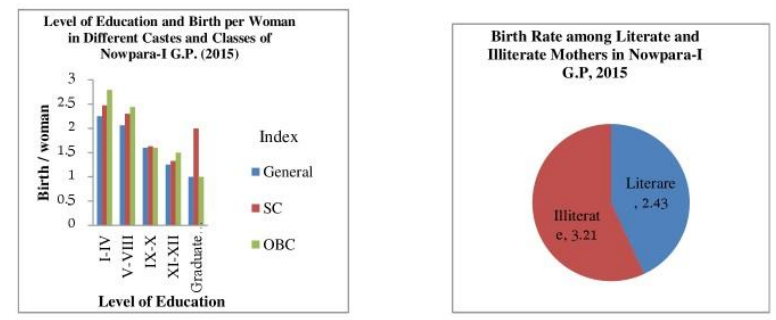

Fig. 6. Birth Rate in different Castes and Classes, 2015 Fig. 7. Birth Rate in Nowpara-I G.P, 2015

\section{Conclusion}

The overall findings demonstrate that literacy rates and levels of education have influences the birth rates. Inequalities in literacy rates are found among different religions, castes and classes due to inequalities in socio-economic components. Birth rates also vary among 
different religions, castes and classes because of inequalities in literacy rates. Birth rates are low among the Hindus when compared with their Muslim counterparts and also low among the general castes people in comparison to the scheduled castes, scheduled tribes and other backward classes. In different educational levels, the birth rates vary because higher levels of education enhances the aspirations for better job, happy family life and reduce the birth rates to small size families. However, inter-village inequalities in literacy rates and in the levels of education are found as burdens to control the birth rates in this GP. So, different measures should be taken up for the development of quality and equitable education in the study area such as establishments of educational institutions (Upper Primary, Secondary, Higher Secondary level and General Degree College), providing monthly stipends, setting up vocational training institutions and creating job opportunities.

\section{References}

Ali, M. A. (2014). A Comparative Study on the Dropout Problem in Primary Education among Muslim Community in Relation to Gender and Economic Status. IOSRJournal of Humanities and Social Science, 19(12), Ver-1, 76-78.

Anonymous. (2011). Sarva Shiksha Abhiyan: Framework for Implementation based on the Right of Children to Free and Compulsory Education Act, 2009. Ministry of Human Resource Development Department of School Education and Literacy, pp. 10

Beteille, A. (1983). Equality and Inequality: Theory and Practice (pp. 1-27). Oxford, Walton Street: Oxford University Press.

Bhattacharyya, R. (2013). Are We Empowered? Stories of Young Indian Working Women, Saarbrücken, Germany: Lap Lambert Academic Publishing, ISBN: 978-3-659-20580-4

Bhattacharyya, R. (2009). Examining the Changing Status and Role of Middle Class Assamese Women: Lessons from the Lives of University Students, PhD thesis, Newcastle University, UK.

Bongaarts, J. (1978). A Framework for Analysing the Proximate Determinant of Fertility. Population Development Review, 105-132.

Breierova, L. \& Duflo, E. (2004). The Impact of Education on Fertility and Child Mortality: Do Fathers Really Matter Less Than Mothers? Working Paper, 10513, National Bureau of Economic Research, Massachusetts Avenue, Cambridge.

Caldwell, J.C. (1980). Mass Education as a Determinant of the Timing of Fertility Decline. Population and Development Review, 6 (2), 225-255.

Census of India. (2001 \& 2011). Primary Census Abstract. Registrar General and Census Commissioner, New Delhi, India, Ministry of Home Affairs. Retrieved from http://www.censusindia.gov.in

Chowdhury, S. \& Sarkar, D. (2012). Gender Inequality in Education Employment of Cochbehar District. International Journal of Social Science Tomorrow, 1 (1), 1-7.

Croix, D. \& Doepke, M. (2003). Inequality and Growth: Why Differential Fertility Matters. The American Economic Review, 93 (4), 1091-1113.

Government of India. (2000). Sarva Shiksha Abhiyan: Programme for Universal Elementary Education in India. Department of Elementary Education and Literacy, Ministry of Human Resource Development, New Delhi, India. Retrieved from www. educationforallinindia.com/ssa.htm

Government of India. (2010). Right to Education. Department of School Education and Literacy, Ministry of Human Resource Development, New Delhi, India. Retrieved from mhrd.gov.in/rte

Johnston, R.J. et al. (2000). The Dictionary of Human Geography (4th ed.). Blackwell: Oxford, England, UK. 
Karlekar, M. (1983). Education and Inequality. In A. Beteille (Ed.), Equality and Inequality: Theory and Practice (pp. 182193). Oxford, Walton Street: Oxford University Press.

Mason, K.O. (1986). The Status of Women: Conceptual and Methodological Issues in Demographic Studies. Sociological Forum, 1(2), 284-300.

Parul, (2014). Disparity in Higher Education: The Context of Scheduled Caste in Indian Society. International Journal of Research in Humanities, Arts and Literature, 2(4), 35-42.

Ramachandran, V., Jandhyala, K. \& Saihjee, A. (2003). Through the Life Cycle of
Children: Factors that Facilitate/ Impede Successful Primary School Completion. Economic and Political Weekly, 38 (47), 4994-5002.

Rindfuss, R., Larry, B. \& St John, C. (1980). Education and Fertility: Implication for the Roles Women Occupy. American Sociological Review, 45 (3), 431-447.

Singh, R. D. (1994). Fertility-Mortality Variation Across LDCs: Women's Education, Labour Force Participation and Contraceptive Use. KYLOS, 47 (2), 209229.

Skirbekk, V. (2008). Fertility Trend by Social Status. Demographic Research, 18 (5), 145-180. 